\title{
ERRATUM
}

Anne T. Saber · Jette Bornholdt - Marianne Dybdahl Anoop K. Sharma · Steffen Loft · Ulla Vogel

Håkan Wallin

\section{Tumor necrosis factor is not required for particle-induced genotoxicity and pulmonary inflammation}

Published online: 19 May 2005

(C) Springer-Verlag 2005

\section{Arch Toxicol (2005) 79:177-182}

In the article mentioned above, the scales of the relative mRNA levels in figure 2 and figure 3 are incorrect.
The relative level of IL- 6 stated in figure 2 should be multiplied by $10^{-9}$ and the relative level of TNF stated in figure 3 should be multiplied by $10^{-7}$.

The online version of the original article can be found at http:// dx.doi.org/10.1007/s00204-004-0613-9

\footnotetext{
A. T. Saber $\cdot$ J. Bornholdt $\cdot$ M. Dybdahl $\cdot$ A. K. Sharma U. Vogel $\cdot$ H. Wallin $(\bowtie)$

National Institute of Occupational Health, Lersø Parkallé 105,

2100 Copenhagen, Denmark

E-mail: hwa@ami.dk

Fax: + 45-39-16-52-01
}

S. Loft

Institute of Public Health, Copenhagen University, 2200 Copenhagen, Denmark 